PP-581

前立腺全摘除術後の再発予測のための GPSM score の有用性の検的

\begin{abstract}
高知医科大学 泌尿器科"
高知県立安芸病院 泌尿器科 ${ }^{21}$

小松 文都",鍈田 雅行", 笠原高太郎", 執印太郎"

阪合 直樹" ${ }^{2}$, 渡辺 裕修"

【目的】前立腺全摘術後の再発を予測するためにBlute らの 考案した GPSM score の有用性の検討を行う。【方法】1990 年 1 月〜1999 年 8 月までの間に高知医科大学泌尿器科と 高知県立安芸病院泌尿器科で術前治療を受けずに前立腺 全摘除術を行った,pT2or3 pN0で術後 3 年以上経過した 75 例 が 対象。Gleason score (G), preoperative PSA (P), margin status $(M)$, seminal vesicle involvement $(S)$, ad-

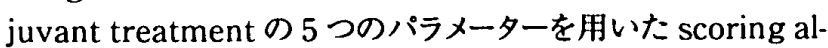
gorithm (GPSM score)か 5 score 別に progression-free survival をもとめ、また,GPSM score の cut-off 值をCox proportional hazards model を用いて決定し、術後再発の 予測に役立つかどうかを検討した。成䌙】GPSM scoreの cut-off 值を 6 とした場合の sensitivity $48.3 \%$, specificity 80\%,PPV 91\%, NPV 27.9\% であった。GPSM score 6 では 前立腺全摘後 3 年、 5 年の progression free survival rate はいずれも71.3\%であった。結論]GPSM scoreは簡易で あり限局性前立腺癌の術後再発の risk を予測する上で有用 であると考えられる。
\end{abstract}

前立眿全摘除術 GPSM score

\section{PP-582 前立腺全摘除術症例の予後の桱的}

\footnotetext{
三要病院附属矢巾クリニック 泌尿器科”三愛病院 泌 尿器科2) 赤坂病院 泌尿器科3) 岩手県立中央病院 泌 尿器科(

根川 恒雄", 岩動一将"2, 杬 多香子"2, 清野 耕治"2)

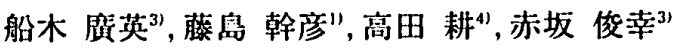

長根 裕"

【目的】前立腺全摘除術後の症约にこついて，摘出摽本の病理結果·Adjuvant 療 法の有無と予後の関保を検討した。奶象と方法】前立腺全摘除術後 1 个月以内 にPSA (Tandem-R)が測定感度以下となり、24ヶ月以上経通勧察が行えた 81

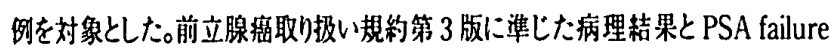
および Adjuvant 盧法の有無と PSA failureについて、Kaplan-Meier 法、比例 ハザードモデルを用いて検討を行った。結果IpT2a 23 例、pT2b 20 例、pT3a 20 湖、pT3b 18 例であった。64 例は Adjuvant 弶法なし、17 例 (pT2a 3 例, pT 3a 4 测.pT3b 10 例)は Adjuvant 廉法を施行していた。PSA failure は 18 例に

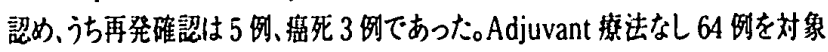
とした比例ハザードモデルでは、ハザード比 v+26.3、cap+13.6.sv+62.6の3 因 子にのみ有意差を認めた。同し对象の Kaplan-Meier 法では，分化度は有意差 ない、ステージは有意差を証めた。全 81 例および pT3 38 例を刘象としたAdjuvant 敦法の有然とPSA failureの検討では、それぞれ $\mathrm{p}=0.44 、 \mathrm{p}=0.09$ と有意 差を認めなかったか、対象を pT3b 18 例に限ると Adjuvant 湶法をした群の方 が有意( $\mathrm{p}=0.01) に$ PSA failure が少なかった。结語]v、cap.svが PSA failureの予测因子であった。アジュバン惊法は pT3bで必要と考元られた。

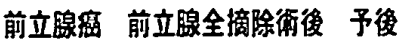

\section{PP-583 PT2NOMO 前立腺㾤における第 8 遭伝子} 变化の FISH 法による検出と臨床的意義

\section{秋田大学 医学部 泌尿器科}

土谷 順彦, 恢藤一成, 加藤 哲郎

【目的】我々は high grade. pT3N0M0 前立腺病において 8q24 領域の增幅をもち、特に $8 \mathrm{p} 22$ 領域の欠失を伴う症例の予後が不 良であることを fluorescent in situ hybridization(FISH)を用い て明らかにした。今回、同様の検討を high grade, pT2N0M0 前 立腺轁に対して行い報告する。対象と方法】Mayo Cllinic で 1987 年から 1991 年までに前立腺全摘術を施行された前立腺㿋 患者のうち Gleason score(GS) ミ6 かつ pT2NOM0である 195 例を对象とした。FISH はパラフイン切片を用い、8p22(LPL)，centromere 8(8cen)ならびに8q24(c-myc)について検討した。【結 果】解析可能であった 156 例のうち 20 例 (12.8\%)に8q24の增 幅、55例 (35.3\%)に 8cen の增加、81 例 $(51.9 \%) に 8 \mathrm{p} 22$ の久失 を認めた。8p22 の久失ならびに 8q24の增幅は GSと有意に相関 した $(\mathrm{P}=0.03, \mathrm{P}=0.02)$ 。単変是解析では $8 \mathrm{p} 22$ の欠失は生物学 的(PSA failure)ならびに臨床的(局所再発·遠隔転移)進展と 相関した $(\mathrm{P}=0.025 . \mathrm{P}=0.011)$ が、多変量解析では有意差を認め なかった。Log rank 解析では $8 \mathrm{p} 22$ の欠失は臨床的進展と有意 に相関し $(\mathrm{P}=0.025) 、 8 \mathrm{p} 22$ の欠失と 8q24 の增幅を有する群では 臨床的進展が层も高率にみられた。考察】pT2NOM0 前立腺癌 において $8 \mathrm{p} 22$ の久失は生物学的ならびに臨床的進展と相関し、 なかでも 8q24 の增幅を伴う例は予後不良な㑯向にあった。 前立腺癌 FISH 第 8 染色体

\section{PP-584 過活動性湭脱に対する塩酸オキシブチニ ン耪胱内注入療法の検討}

\begin{abstract}
労働福祉事業団 総合せき損センター 泌尿器科
西井 久枝, 岩坪暎二, 木元 康介

目的:抗コリン剂内服、カプサイシン膀胱内注入療法、レジニ フェラトキシン膀胱内注入療法が無効であった過活動性膀胱 による尿失禁 65 症例に対し、塭酸オキシブチニン膀胱内注 入療法を行い、尿失禁の変化、膀胱内压測定_上の変化、副 作用などについて検討した。方法:塩酸オキシブチニン(商品 名ポラキス) 2 錠 $6 \mathrm{~m}$ を粉末状とし生理食塩水 $20 \mathrm{ml}$ に溶解、 間歇導尿後に1日 2 回膀胱内に注入した。対象:男性 39 名、女性 26 名、合計 65 名。疾患内訳は䅡暍損伤が 14 名、

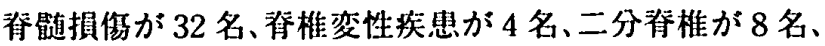
神経変性疾患が 2 名、その他 5 名。結果:32名が平均 4.9 ヶ 月膀胱内注入を継続。全身副作用の軽隇、失紫コントロール 可能となっており患者満足度も高い。
\end{abstract}

過活動性膀脱 塩酸オキシブチニン 賠胱内注入痖法 